\title{
The Pacifism in Hayao Miyazaki's Animation Art
}

\author{
Sancong Zhang
}

Jingdezhen University of ceramics, Jiangxi 333403, China

Keywords: Hayao Miyazaki, animation, pacifism, antiwar, and green peace.

\begin{abstract}
With the release of Hayat Miyazaki's new animation "the wind" and Hayat Miyazaki's opposition to the publication of the Undouble government's revisions to the peace constitution, the peace doctrine of the Japanese animation giant has aroused wide attention again, looking at Hayat Miyazaki's "the valley of the wind", "the city of the sky", "the red pig", "hart's shift". The animated film, such as the animated castle, has a clear embodiment of his pacifism. The article starts with the embodiment of the peaceful thought in his animation, and probes into the causes of its peaceful thought.
\end{abstract}

\section{Introduction}

In July 20, 2013, Hayat Miyazaki, who had been away from the audience for 5 years, returned to the public's vision with his new work, "windy". On the eve of the film, Hayat Miyazaki wrote in the hot wind, the free issue of the magazine "hot wind", which is free by the studio of glibly. (Undouble) the government's vote rate and turnout rate in the general election are not high, but it is simply unreasonable to try to use the method of beating the head to make changes in the constitution. I really think so. It is also unknowable that the government will amend the constitution ninety-sixth times at the legal level, and it may be a fraud after that. After criticizing the irresponsible behavior of the Undouble administration, he also put forward his own views on the crimes, the comfort women and the territorial disputes in China during the Second World War. After the publication of the article, the Japanese right-wing native even scolded him as an "Anti-Japanese traitor". He thought he failed to consider the Japanese mood and was disappointed in his "non patriotic behavior". Though attacked by Japanese Rightists, his righteous remarks were praised by the Chinese people and the people of Japan and China, who were invaded by World War II. Hayat Miyazaki's comments on the pacifism and the audience who are familiar with Hayat Miyazaki's animations should not be sudden, because his pacifism is reflected in his animated animations such as the valley of the wind, the city of the sky, the red pig, and the mobile castle of Hal.

\section{Hayat Miyazaki's Pacifism in Animation Art}

\subsection{Oppose War and Advocate Peaceful Coexistence of Human Society.}

He has a complete negative attitude towards war, and he thinks that the result of war can only lead to failure and destruction, and his thought is reflected in many animated cartoons. In the valley of the wind, human beings had a highly developed industrial civilization before 1000 . They made great weapons of great power. The final "seven day fire" war almost completely destroyed human civilization, only a few people survived. In his new work "the wind", Horikoshi Jira worked hard to design the dream of the plane, but his dream was used by the fascist and militarists at that time. Horikoshi Jira was trapped in the whirlpool of ideal and reality, and finally he designed an aircraft with excellent performance, but these planes became a killing tool in the war. After being shot down into the remains of a frame, Horikoshi Jiri's dream finally destroyed and the country was also defeated by war.

Hayat Miyazaki's hatred of war is also reflected in the details of his animation. Although many of his animations were against the background of war, there was not much battle scene, and he did not want to describe the war scenes so much that he was suspected of beautifying the war. Throughout his animated films, the scenes of war are all dark, even dirty, and have a strong contrast with the bright 
and bright pictures of other parts of the film blue sky, white clouds, and green trees. His idea is also reflected in the setting of some flying props. In the valley of the wind, notice, the representative of the representative, drives a flying wing like a pigeon, with a simple shape and a bright color, while the cob warships of the Lu Mei Kia kingdom are dark, ugly and weird with a sense of evil. The white delta wing glider of the city of sky and Bare also has a similar contrast with the air gun, Goliath, full of artillery. These war machines are often portrayed as giant creatures, looking fearful, but ultimately unable to escape the fate of being ruthlessly destroyed.

In Hayat Miyazaki's animated movies, different from the positive roles of an angel girl and a brave teenager, the role of war making is often portrayed as ruthless and extremely greedy. In order to inflate their selfish desires, they provoke war, kill innocence, and end up in failure and destruction. In "future young Conan", the great ambition, the great ambition, to search for Lana, to kill Conan's grandfather, and to Conan many times the pain of the killer, he launched a coup, delusional hegemony of the world, and finally fell to the end of the death of the downfield. Moussa and hid in the city of the sky are also the descendants of the sky city of pula, but hidden beneath his well - dressed appearance is an ambitious, unsympathetic conspiracy. He seeks to conquer the world by the advanced technology of La PADDA, and eventually with the collapse of the city of the sky, his ambition. In the air, I fell from the city of the sky.

\subsection{Green Peace, Concern about the Relationship between Man and Nature.}

Another important component of Hayat Miyazaki's pacifism is to pay close attention to the relationship between ecology and human beings and advocate green peace. His animation conveys the message that nature is beautiful and our common homeland. Human beings should have reverence when facing the nature. In the valley of the wind, the canyon inhabited by nutsaxa is like the shady trees of the world, the wind and the wind, the wind and the wind, and the life of mankind and other creatures, have become the safe haven of human safety in the heavily polluted environment. In the princess of the ghost, the earth is covered with luxuriant forests, mountains and fog, in ancient forests, streams and mirrors, and human beings and other animals live in this forest. The nature he describes is full of vitality and awesome. The "rotten sea" in the valley of the wind constantly spore spores, and humans can't get close to them. They can purify the land and water polluted by the thermonuclear war one thousand years ago, and the insects guard the "rotten sea" to prevent human beings from continuing to encroach on the earth. The forest in the ghost princess lives in all kinds of gods, the White Wolf God Mona, the wild boar God B, the common guardian of the forest, the orangutans planting trees on the land destroyed by human beings, the keeling animals in the forest, and the divine power endowed with life in the world.

On the other hand, Hayat Miyazaki objected to the excessive nature of human beings claiming that the act of destroying nature is bound to be punished by nature. In the valley of the wind, the human being killed each other because of the use of "giant soldiers", which eventually led to the destruction of the forest, the river was polluted into poisonous water, and the lake was radiated into a strong acid lake. Even after one thousand years, the ecology had not been restored, and the surviving human beings had to survive on the edge of the "rotten sea", like in the film. The old man said, "Fire burns ashes to forests in one day, and water and wind need more than one hundred years to reforestation." In the ghost princess, the iron town of the magic, in order to make iron making weapons, keeps cutting down the forest, and the trees around the iron town are cut down, looking like a scar of the earth. Asif Dhaka was cursed in the battle with the magic God and left unhealed wounds in his arms. In the Iron Town, there are many people who have been cursed in the battle to destroy the forest, and the whole body scars cannot be healed to survive, which indicates that human destruction of nature is like the destruction and trampling of its own body. Hayat Miyazaki believed that human beings regard themselves as the masters of nature and that they want to get everything in the world for their own interests, which is a sin in itself.

For the solution of the contradiction between man and nature, Hayat Miyazaki advocated human self-salvation. In the valley of the wind, NNA urinal, in order to stop the attack of the king's worm, sacrificed his life solemnly, and returned the Wang worm's larva to the anger of the Wang bug, and the Wang bug was grateful to maraca and resurrected her with golden tentacles. In the princess of the 
ghost, the kylin beast, which was taken away from the first level, withered and withered the life of the Kirin and Asif Dhaka. Human beings should make up for and repair the destroyed nature and save themselves. In turn, nature will give the corresponding gifts to mankind.

\section{The Cause Of Pacifism in Hayat Miyazaki's Animation}

\subsection{The Shadow of War in Childhood Memory.}

In 1941, Hayat Miyazaki was born in Tokyo, Japan, that is, in December 7th of this year, Japan attacked the Pearl Harbor of the United States, and the Pacific War broke out. 3 years later, the war had been made in Japan, and many of the Japanese military products were made by small family workshops, and these small businesses were scattered among the residential areas in Tokyo. In order to completely paralyze the Japanese military industry, they were forced to surrender. In from March 9 to 10,1945 , the US bombers used a burning bomb. Large-scale bombardment was carried out in the urban area of Tokyo. Because most of the Japanese dwellings were built of wooden structures, the fire spread rapidly, and there was a fire whirlwind above the urban area, and 1/4 of Tokyo's blocks were razed to the ground. At that time, the Hayat Miyazaki family had moved away from Tokyo, and his father, in order to confirm the safety of his relatives, entered the city of Tokyo on the second day of the bombing, witnessing a piece of ruins and the tragic death of the dead. Hayat Miyazaki, directly and indirectly, heard the adults' description of the brutal war scenes and experienced the horror of the war. "My childhood memory at the age of 4 was to pull my father's hand and run around the fire and rain." He witnessed the bombardment of the neighborhoods submerged in the fire, the mother and daughter who were unable to get on the train in the air raid siren and wept in situ. These all prick his mind. In his later works, we will often see these horrific war scenes. In the prelude of the valley of the wind, the ancient giant soldiers appeared in the picture like ghosts. Their seven day fire destroyed the highly developed industrial civilization of mankind. The city was burned and the people struggled in the fire. In Hal's mobile castle, the flying warship was filled with bombs and thrown over the city. The city below is in ruins, and the flames are soaring. The pictures depicting the war are repressed and horrifying, just like nightmares. Hayat Miyazaki felt a deep disgrace and disgust for the war of aggression in Japan during World War II. "I only had a sense of" really a stupid war in my childhood. "At that time, some adults talked amorously about the Japanese army's mischief in the mainland of China. I heard these things several times. Rumors of all kinds of mess came into my ears, when I thought I was born in a country where I was a bastard. I really hate Japan.

\subsection{The Impact of the Situation at Home and Abroad.}

Hayat Miyazaki's understanding of war in childhood was ignorant. As he grew up, Hayat Miyazaki began to contact left-wing films, read left-wing literary works, and accept socialist theory. He participated in the demonstration of the Anti-Japanese and American security struggle in 1960, and after his work, he was more actively engaged in the struggle of trade unions, gradually taking postwar democracy and pacifism as their lifelong political position. As a military fan, Hayat Miyazaki, a military fan after his adult life, looked up a large number of military historical data, especially when he read the "Zhao he history" of the half of the rattan, and became more aware of the misdeeds of Japan in World War II so that he would not be able to read it. He often thinks, "Why did Japan go to other countries to fight like that? Is there no other way out? "With the dramatic changes in Eastern Europe and the disintegration of the Soviet Union, the Gulf War, and the Southern Union civil war, Hayat Miyazaki had a more profound understanding of the war: "as long as the war begins, there is no justice, there is no justice and injustice in the war, and it is the performance of human ugly nature."

In Japan, right-wing forces have been intensifying in recent years, and Hayat Miyazaki feels an unprecedented sense of urgency. 2012 when Hayat Miyazaki is writing his new film "the wind", the Japanese government's nationalization of the Diary Island has caused a strong reaction between the Chinese government and the people. The ships are constantly confronting the Diary Islands, and the situation becomes tenser. Hayat Miyazaki feels that the tension in the "wind" film is being staged. "The documentary" the rise of the wind "1000 days of the creation of a record," said: "there is a feeling of the eve of war"; "some girls become strong, go to another world what, these content is not 
suitable for today's time, because the times are more horrifying, no way to solve." In 2013, the attempt by Japanese Prime Minister Abe to amend the Japanese Peace Constitution has aroused the vigilance of the pacifists at home and abroad in Japan. Hayat Miyazaki is a rare writer and a direct attack. The rise of the wind tells the story of the ideal error error in the turbulent times before the war of Japan, and, similarly, the premonition of the change of Hayat Miyazaki, which still persists in his pacifism, as described in the present times.

\subsection{The Imprint of the Forest Culture.}

Japan is a large forest country with $2 / 3$ of its total area covered by forests. The ancestors of Japan have lived in such natural environment. They live together with the forest, live in harmony, get the resources of life and production from the forest, carry out religious activities, and have affectionate and awe inspiring feelings to the great nature. As Japanese scholar Mei Yuanmeng said, "the forest belief in the heart of the Japanese is the core of the Japanese religious thought and the backbone of the Japanese spiritual ideological structure," as the Japanese scholar, a Japanese scholar, said. When Hayat Miyazaki worked with Lord GAO for "the great adventure of sun Prince Holes", he collected information and read the book "the origin of cultivated plants and farming" by the botanist Macao Sauce. He accepted Macao Sauce’s "sham leaf forest culture theory". Hayat Miyazaki had done the following description: "at the end of the reading of the article." My vision was brought to a remote height. Far away from national boundaries, racial barriers and heavy history, I like the smell of natty and sticky food, and I smell the life of broad-leaved forest. This book provides a starting point for me to see things. Let me have a better understanding of history, land and country. "Macao Sauce's theory made Hayat Miyazaki's cognition beyond the shackles of the nation and the nation, and the footsteps were far from the heavy history, and he finally liberated himself from the self-curse of "hating Japan" and "being humiliated for himself as a Japanese". In the creation of "the third world of the grand theft", Hayek Miyazaki took "illuminate the leaf forest" as the source, gave himself a pen name "shining the tree". From then on, "illuminate the leaf forest culture" rooted in his creative thought. He began to make artistic imagination and creation of the forest of the source of life, and the forest as a natural representation. It is a symbolic element to explore the relationship between man and nature in Hayek Miyazaki animation.

\section{References}

[1] Hayek Miyazaki, Hayek Miyazaki's miscellaneous notes, Japanese painting 1997.

[2] Xu Yanking, master of world animation film, Communication University of China press, 2006.

[3] Yang Xiaoping, animation master Hayek Miyazaki, Furan University press, 2011.

[4] Glibly studio "hot wind" July 2013 special edition "constitution amendment" July 2013 Edition. 